\title{
Chapter 8 \\ Rice Straw Incorporation Influences Nutrient Cycling and Soil Organic Matter
}

\author{
Pauline Chivenge, Francis Rubianes, Duong Van Chin, Tran Van Thach, \\ Vu Tien Khang, Ryan R. Romasanta, Nguyen Van Hung, and Mai Van Trinh
}

\begin{abstract}
Rice straw incorporation is labor-intensive and influences greenhouse gas emissions but can increase soil organic carbon $(\mathrm{C})$ and recycle nutrients. Rice straw contains about 80,40 , and $30 \%$ of the potassium $(\mathrm{K})$, nitrogen $(\mathrm{N})$, and phosphorus $(\mathrm{P})$, respectively, taken up by rice and thus its incorporation can reduce the fertilizer requirement of the subsequent crop. However, because of rice straw's low quality, its decomposition is slow. So, the timing of this operation, in combination with water management, becomes important. Composting rice straw with the addition of farmyard manure can improve quality and nutrient supply. Similarly, biochar from thermal combustion of rice straw for energy production can be added to the soil to improve soil organic $\mathrm{C}$. This chapter highlights the benefits derived from incorporating straw into the soil. Alternative forms of straw that can be used by farmers, depending on local situations, are discussed.
\end{abstract}

Keywords Soil organic carbon · Straw management · Nutrient supply · Micronutrients $\cdot$ Decomposition

P. Chivenge $(\triangle) \cdot$ F. Rubianes $\cdot$ R. R. Romasanta $\cdot$ N. V. Hung

International Rice Research Institute (IRRI), Los Baños, Laguna, Philippines

e-mail: p.chivenge@irri.org; F.Rubianes@irri.org; r.romasanta@irri.org; hung.nguyen@irri.org

D. Van Chin

Dinh Thanh Agricultural Research Center, Loc Troi Group, Hoa Tan Hamlet,

Thoai Son District, An Giang, Vietnam

T. Van Thach

Dinh Thanh Agricultural Research Center (DTARC), Loc Troi Group, Hoa Tan Hamlet,

Thoai Son District, An Giang, Vietnam

V. T. Khang

Cuu Long Rice Research Institute, Can Tho City, Vietnam

M. Van Trinh

Institute of Agricultural Environment, Nam Tu Liem District, Hanoi, Vietnam 


\subsection{Introduction}

Rice straw management after harvest is an important component of the rice production cycle, particularly in Asia where $90 \%$ of the world's rice is produced, and, consequently, where the bulk of the straw is produced. Traditionally in Asia, rice is manually harvested by cutting and carrying to a central threshing location for separation of grain and straw, with only a small portion of straw retained in the field. Straw was considered a waste product and was either burned or used for other purposes such as fodder or animal bedding. However, the increasing use of combine harvesters in the region has resulted in large amounts of rice straw being left in field. The in-situ incorporation of rice straw in the soil has been shown to contribute to recycling of nutrients and increasing soil organic carbon (C) and yields of subsequent crops (Bijay-Singh et al. 2004; Gupta et al. 2007).

While rice straw contains significant amounts of nutrients, its incorporation into the soil is labor-intensive and affects seedbed preparation and crop establishment. This makes land preparation expensive compared to the common practice of openfield burning. On the other hand, straw burning releases particulate matter into the atmosphere, which is associated with air pollution and human respiratory ailments. This has led to bans on open-field straw burning in most major rice-producing countries, although such policies have been largely difficult to enforce. The production of two or three rice crops annually results in the production of large quantities of straw, with little turnaround time between crops, particularly where three crops are grown annually. This results in limited decomposition of the straw when incorporated, with potential negative effects on nutrient availability and use efficiency of applied fertilizers for the subsequent crop (Bijay-Singh et al. 2004; Dobermann and Fairhurst 2000). Depending on the type of water management following straw incorporation, greenhouse gas emissions (GHEs) can also increase (Sander et al. 2014).

Large amounts of rice straw left in the field have posed challenges in ricegrowing areas because of the need for mechanization and multiple tillage operations to enable effective incorporation of the straw into the soil. Similarly, the adoption of no-till in rice-cropping systems has been limited by the presence of the large amounts of straw on the soil surface where combine harvesters are used. However, equipment innovations have been developed, such as the Happy Seeder, to enable direct seed drilling while cutting the standing stubble into mulch (Sidhu et al. 2007). Straw incorporation, nonetheless, benefits the next crop and ecosystem services, in general, depending on management practices and the cropping system employed. Incorporating straw in rice fields serves as a source of food for an array of fauna that use rice fields as a habitat. For example, Schmidt et al. (2015) noted that rice straw provides substrate to promote biodiversity through flourishing of invertebrates that decompose the straw, which in turn enhances nutrient cycling in paddy soils. This chapter provides information on the benefits and challenges associated with incorporating rice straw into the soil, including alternative forms through which rice straw can be used as a soil amendment. 


\subsection{Different Components of Rice Straw}

At harvest, rice biomass includes rice straw and paddy grain, which is partitioned into milled grain, bran, and husks after milling. On average, particularly for modern high-yielding varieties, the harvest index (i.e., grain dry weight: total plant biomass dry weight) of rice is between 0.45 and 0.50 (Dobermann and Fairhurst 2000). Thus, roughly for every ton of rice grain produced, a ton of rice straw is also produced. Rice straw usually has higher moisture content than the husks and bran because it is obtained during harvest whereas the bran and husks are drier because they are obtained after dried paddy is milled. When rice is harvested, the straw is removed from the field for threshing to separate grains while the stalk and the stubble remain in the field. The amount of stubble depends on the height at which the straw is cut. The stubble is usually retained in situ and is either burned or incorporated into the soil during land preparation. Rice husks are the parts that are removed when milling paddy to make brown rice while the bran is the layer that is then removed when brown rice is polished to make white rice. Depending on the processing, the different rice plant components other than the grain can be collected and used for composting, biofuel production, or other purposes. Composted materials can be returned to the same soil or applied to the fields of other crops, usually of high value, resulting in the export of nutrients.

\subsection{Forms in Which Rice Straw Is Returned to the Soil}

Due to ease of management, the main form in which rice straw is currently returned to the soil is by incorporating burned ash after open-field burning of stubble following harvest. However, with the banning of straw burning in most rice-growing countries, incorporating fresh rice residue serves as the alternative for returning rice straw to rice fields. While this is associated with benefits of improving soil quality and recycling nutrients, it can have negative impacts on the environment through release of GHGs, depending on management. Alternatively, the straw is collected from the field and mixed with other inputs such as livestock manure, green manure, or household waste to make compost, which is more decomposed and of higher quality compared to fresh straw. In other instances, earthworms and microorganisms are added to the straw to enhance decomposition to make vermicompost (see Chap. 3). Compost and vermicompost can be made from fresh or spent straw from mushroom production, but farmers generally prefer to use them for high-value crops such as vegetables rather than for rice production. The straw can be used in energy production and the carbonized rice straw that remains can be used as a soil amendment (Haefele et al. 2011). 


\subsection{Straw Effects on Soil Properties}

\subsubsection{Nutrient Cycling}

The incorporation of rice straw can improve soil quality through enhanced nutrient cycling and soil organic $\mathrm{C}$ sequestration. Straw incorporation has been shown to enhance nutrient recycling and provide soil fertility benefits (Dobermann and Fairhurst 2000; Ponnamperuma 1984; Yadvinder-Singh et al. 2004). The straw is the main organic material that is available for most rice farmers and serves as an important source of K. Ponnamperuma (1984) indicated that, at harvest, the straw contains $0.57 \% \mathrm{~N}, 0.07 \% \mathrm{P}_{2} \mathrm{O}_{5}, 1.5 \% \mathrm{~K}_{2} \mathrm{O}, 0.1 \%$ (sulfur) $\mathrm{S}$, and $5 \%$ silicon ( $\mathrm{Si}$ ). In agreement, Dobermann and Fairhurst (2002) also showed that rice straw at harvest can contain $0.5-0.8 \% \mathrm{~N}, 0.07-0.12 \% \mathrm{P}_{2} \mathrm{O}_{5}, 1.16-1.66 \% \mathrm{~K}_{2} \mathrm{O}, 0.05-0.1 \% \mathrm{~S}$, and 4-7\% Si. This translates to about 40\%, 30-35\%, 80-85\%, 40-50\%, and 80\%, respectively, of the $\mathrm{N}, \mathrm{P}_{2} \mathrm{O}_{5}, \mathrm{~K}_{2} \mathrm{O}, \mathrm{S}$, and $\mathrm{Si}$ taken up by the plant. The addition of rice straw was shown to improve soil $\mathrm{pH}$, soil organic $\mathrm{C}$, and nutrient content compared to the initial conditions in a study conducted in Vietnam (Table 8.1) (Thanh et al. 2016). In that study, the incorporation of rice straw resulted in greater increases in soil organic $\mathrm{C}, \mathrm{pH}$, and nutrient contents compared to addition of ash from burned straw, although the increase in $\mathrm{N}$ was small. Due to the low $\mathrm{N}$ content in straw, large quantities would be needed to supply adequate amounts of N. However, the straw has to decompose before the nutrients can become available for uptake and the rate of decomposition and supply of nutrients depends on soil type and season. Additionally, only a proportion of the nutrients become available in the season of application. For example, in a study on an alluvial soil in Vietnam, about 67 to $69 \%$ of the rice straw had decomposed by the time the plant had reached physiological maturity (Thuan and Long 2010).

The availability of nutrients is affected by the low quality of rice straw, with a high $\mathrm{C}: \mathrm{N}$ ratio, resulting in slow decomposition and mineralization of nutrients, particularly short-term availability of $\mathrm{N}$ and to some extent $\mathrm{P}$ (Thuy et al. 2008). The $\mathrm{C}: \mathrm{N}$ ratio of an organic material determines its quality, with high $\mathrm{C}: \mathrm{N}$ ratio representing low quality and a slow rate of decomposition, whereas low $\mathrm{C}: \mathrm{N}$ ratio represents high quality with a faster decomposition. The addition of rice straw to wet soil results in temporary immobilization of nitrogen, making it unavailable and affecting rice yields (Bird et al. 2001). Apart from low straw quality, $\mathrm{N}$ availability following

Table 8.1 Effects of rice straw and ash from rice straw on soil chemical properties

\begin{tabular}{|c|c|c|c|c|c|}
\hline \multirow[b]{2}{*}{ Treatment } & \multirow[b]{2}{*}{$\mathrm{pH}_{\mathrm{KCl}}$} & $\mathrm{SOC}^{\mathrm{a}}$ & $\mathrm{N}$ & $\mathrm{P}_{2} \mathrm{O}_{5}$ & $\mathrm{~K}_{2} \mathrm{O}$ \\
\hline & & \multicolumn{4}{|l|}{$(\%)$} \\
\hline Before experiment & 4.10 & 0.80 & 0.08 & 0.034 & 0.52 \\
\hline Ash from $5 \mathrm{tha}^{-1}$ rice straw & 4.32 & 1.09 & 0.09 & 0.046 & 0.60 \\
\hline $5 \mathrm{t} \mathrm{ha}^{-1}$ fresh rice straw & 4.40 & 1.19 & 0.11 & 0.041 & 0.55 \\
\hline
\end{tabular}

Source: Thanh et al. (2016)

${ }^{\text {aSOC }}$ soil organic C 
incorporation of the straw is affected by the accumulation of phenolic compounds that are formed under the straw's anaerobic decomposition (Olk et al. 2006). These phenolic compounds tend to bind the $\mathrm{N}$ in the soil making it unavailable for plant uptake.

Nonetheless, the long-term incorporation of crop residues in flooded rice soil can increase soil organic matter, total $\mathrm{N}$, and soil biological activity (Yadvinder-Singh et al. 2004). Continuous incorporation of crop residues after each crop can eventually increase the $\mathrm{N}$-supplying capacity of rice soils (Eagle et al. 2000). In a study in Vietnam, soil $\mathrm{N}$ increased from $0.65 \%$ to $0.085 \%$ following 9 years of cropping with incorporation of rice straw while straw removal caused a decline in soil $\mathrm{N}$ (Thuan and Long 2010). The benefits of incorporated residues on soil organic matter and soil $\mathrm{N}$ supply, however, seldom translate into increased yield or profit for flooded rice (Bijay-Singh et al. 2008). However, Thanh et al. (2016) observed that $\mathrm{N}$ fertilizer requirement was reduced by about $20 \%$ in a long-term study with rice straw incorporation.

Timings of straw incorporation and water management are important considerations for effective use of straw as a nutrient resource (Dobermann and Fairhurst 2002; Witt et al. 2000). Rice straw should be incorporated in dry soil at least 3 weeks before sowing or transplanting the next crop to allow the straw to decompose aerobically. This minimizes the negative effects of anaerobic decomposition, which results in release of phenolic compounds (Olk et al. 2006), and methane emissions (Sander et al. 2014), while allowing for decomposition and mineralization of the nutrients, making them available during plant growth. In a cropping system comparing rice-rice to rice-maize, $\mathrm{N}$ supply was greater when residue incorporation took place 63 rather than 14 days before planting wet season rice; this was associated with greater rice yields (Witt et al. 2000). This points to the need for time for straw decomposition before the nutrients become available for plant uptake. Rice straw compost, on the other hand, because it is more decomposed before its application in the soil, has greater nutrient availability compared to raw rice straw. However, farmers prioritize the use of compost on higher-value crops such as vegetables than on rice.

Rice straw can serve as an important source of $\mathrm{S}$, which is particularly important in situations where S-free fertilizers are used (Dobermann and Fairhurst 2002). It also serves as an important source of micronutrients including zinc (Zn), but its long-term application can decrease the availability of $\mathrm{Zn}$ (Yadvinder-Singh et al. 2005). Rice straw is also important for $P$ recycling. For example, in a 4-year study in India, $\mathrm{P}$ balances were negative where rice and wheat straw were removed or burned (Gupta et al. 2007). The mineral P dynamics were improved where P fertilizers were added. Similarly, Gangwar et al. (2006) observed greater concentrations of plant available $\mathrm{P}$ when rice straw was incorporated compared to when it was removed in a 3-year rice-wheat study. Continuous addition of biochar made from rice straw on a degraded soil in Soc Son District of Hanoi resulted in an increase in soil $\mathrm{pH}$, cation exchange capacity, and soil organic $\mathrm{C}$ after four seasons (Table 8.2A) (Trinh et al. 2011). Biochar has high soil $\mathrm{pH}$ and tends to have a liming effect in soil, while it is also stable and decomposes slowly, resulting in an increase in soil organic 
Table 8.2 Soil properties before and after four rice seasons of continuous application of (A) biochar from rice husks or straw compared to farmyard manure and mineral NPK fertilizer in Soc Son District, Hanoi, Vietnam, and (B) NPK fertilizer compared to biochar, compost from rice straw, and compost from rice straw mushroom solid waste on three sites; Thai Binh, Hung Yen, and Hai Duong provinces in Red River Delta, Vietnam

\begin{tabular}{|c|c|c|c|c|c|c|c|c|}
\hline \multirow[b]{2}{*}{ Treatment } & \multirow[b]{2}{*}{$\mathrm{pH}_{\mathrm{H} 20}$} & $\mathrm{~N}$ & $\mathrm{P}_{2} \mathrm{O}_{5}$ & $\mathrm{~K}_{2} \mathrm{O}$ & $\mathrm{SOC}^{\mathrm{a}}$ & CEC & $\mathrm{Ca}$ & \multirow[b]{2}{*}{$\mathrm{Mg}$} \\
\hline & & \multicolumn{4}{|l|}{$(\%)$} & \multicolumn{2}{|c|}{$\begin{array}{l}\left(\mathrm{cmolc}_{+}\right. \\
\left.\mathrm{kg}^{-1}\right)\end{array}$} & \\
\hline \multicolumn{9}{|l|}{ A. Trinh et al. (2011) } \\
\hline Before experiment & 5.02 & 0.13 & 0.07 & 0.22 & 1.33 & 9.24 & 2.04 & 0.21 \\
\hline No fertilizer (control) & 5.20 & 0.10 & 0.09 & 0.21 & 1.10 & 10.4 & 2.74 & 0.09 \\
\hline NPK fertilizer & 5.25 & 0.15 & 0.11 & 0.27 & 1.27 & 10.6 & 3.51 & 0.25 \\
\hline Farmyard manure $\left(10 \mathrm{t} \mathrm{ha}^{-1}\right)$ & 5.24 & 0.15 & 0.10 & 0.28 & 1.62 & 11.5 & 3.59 & 0.35 \\
\hline Rice husk biochar $\left(1.5 \mathrm{t} \mathrm{ha}^{-1}\right)^{\mathrm{b}}$ & 5.30 & 0.17 & 0.11 & 0.33 & 1.83 & 11.6 & 3.48 & 0.35 \\
\hline Rice husk biochar $\left(3.0 \mathrm{t} \mathrm{ha}^{-1}\right)$ & 5.31 & 0.17 & 0.11 & 0.31 & 1.89 & 14.7 & 3.82 & 0.48 \\
\hline Rice straw biochar $\left(1.5 \mathrm{t} \mathrm{ha}^{-1}\right)^{\mathrm{b}}$ & 5.39 & 0.17 & 0.13 & 0.32 & 1.85 & 13.6 & 3.55 & 0.36 \\
\hline Rice straw biochar $\left(3.0 \mathrm{t} \mathrm{ha}^{-1}\right)$ & 5.45 & 0.17 & 0.12 & 0.32 & 1.79 & 14.5 & 4.02 & 0.45 \\
\hline Rice straw biochar $\left(4.5 \mathrm{t} \mathrm{ha}^{-1}\right)$ & 5.40 & 0.18 & 0.14 & 0.35 & 1.82 & 15.2 & 4.11 & 0.48 \\
\hline \multicolumn{9}{|l|}{ B. Trinh et al. (2014) } \\
\hline NPK fertilizer & 5.54 & 0.21 & 0.18 & 1.56 & 2.05 & 14.29 & & \\
\hline Biochar & 5.82 & 0.23 & 0.20 & 1.49 & 2.31 & 16.52 & & \\
\hline Compost from straw & 5.86 & 0.22 & 0.22 & 1.57 & 2.35 & 16.24 & & \\
\hline Compost from straw mushroom waste & 5.81 & 0.21 & 0.20 & 1.72 & 2.18 & 17.29 & & \\
\hline
\end{tabular}

In all the treatments for both studies, NPK fertilizers were added, except for the no fertilizer control treatment ${ }^{\text {a SOC }}$ soil organic $\mathrm{C}$

${ }^{\mathrm{b}}$ The amount of $\mathrm{C}$ in this treatment is equal to amount of $\mathrm{C}$ in 10 tons of Farmyard Manure

C. Soil water and nutrient holding capacity were also increased, likely due to the porous nature of biochar, with an indirect increase in rice yield. A separate study conducted in Thai Binh, Hung Yen, and Hai Duong provinces in the Red Delta in Vietnam showed significant improvement in soil fertility following the addition of rice straw and products from rice straw (biochar, compost, compost from rice straw mushroom; Table 8.2B) (Trinh et al. 2014).

\subsubsection{Soil Organic Carbon}

The sequestration of organic $\mathrm{C}$ in soil is generally considered a win-win situation because of its contribution to the mitigation of GHGs from the atmosphere while improving soil quality. Burning of straw, on the other hand, results in combustion of the $\mathrm{C}$ in the straw and loss into the atmosphere, associated with production of GHGs (see Chap. 10). Soil organic $\mathrm{C}$ is an important component of the global $\mathrm{C}$ cycle and is considered an indicator of soil quality and a measure of sustainability. Soil organic $\mathrm{C}$ is the main component of soil organic matter, which plays an important role in the 
supply of nutrients and improves biological and physical properties of the soil. Rice straw incorporation has been shown to increase soil organic $\mathrm{C}$ (Tables 8.1 and 8.2). However, the role of soil organic $\mathrm{C}$ in rice soils remains debatable. While soil organic $\mathrm{C}$ is considered important on one hand, the increased GHG emissions associated with increased soil organic $\mathrm{C}$ can contribute to climate change. Thus, there is need to evaluate the tradeoffs and synergies of soil organic $\mathrm{C}$ sequestration in rice soils.

Soil organic $\mathrm{C}$ has been shown to be stable under intensive rice cropping, even when straw is removed from the field. Soil organic $\mathrm{C}$ was shown not to change in a 50-year, long-term continuous cropping experiment at the International Rice Research (IRRI) in the Philippines where three rice crops were grown annually with the removal of all aboveground biomass even without the addition of $\mathrm{N}$ fertilizer (Pampolino et al. 2008). This is in contrast to systems where rice is rotated with an upland crop, e.g., Majumder et al. (2008) observed a decline in soil organic $\mathrm{C}$ when no residues were added in a rice-wheat cropping system in India. In a 9-year study in Bac Giang Province in Vietnam, soil organic C did not change with straw removal, but the addition of straw increased soil organic $\mathrm{C}$ from $1.28 \%$ to $1.65 \%$ (Thuan and Long 2010). Alberto et al. (2015) showed a cumulative effect of continuous straw incorporation in a lowland rice soil, likely due to slower organic matter decomposition. However, the addition of straw increases soil organic C (Bi et al. 2009; Yadvinder-Singh et al. 2005), particularly in rainfed upland rice systems (Naklang et al. 1999) or where lowland rice is rotated with an upland crop. In a rice-wheat system, Gangwar et al. (2006) observed greater soil organic C and infiltration when $5 \mathrm{t} \mathrm{ha}^{-1}$ rice straw was incorporated in the soil than when it was removed or burned.

\subsection{Rice Straw Effects on Yield}

While yield increases are expected with the retention of crop residues in upland cropping systems, in lowland rice the benefits when compared to straw removal are small particularly in the short-term. Under continuous flooded rice, the retention of rice straw has not been shown to increase rice yield. This might be due to the lowquality nature of rice straw with a high $\mathrm{C}: \mathrm{N}$ ratio, which results in $\mathrm{N}$ immobilization and hence poor availability for plant uptake. Additionally, anaerobic decomposition of organic materials has been shown to trigger production of phenolic compounds that also renders $\mathrm{N}$ to be unavailable and affect crop growth. Incorporation of rice straw on three different soil types did not increase rice yield and this was attributed to an increase in toxic substances and organic acids (Hoi et al. 2009). This is particularly important when the straw has not been given adequate time for decomposition. However, long-term benefits of straw incorporation on rice yield can be significant. A summary of some studies conducted in the Philippines and Vietnam shows yield benefits from straw incorporation (Table 8.3).

In a long-term study in the Mekong Delta in Vietnam (Watanabe et al. 2009) observed that the application of $6 \mathrm{Mg} \mathrm{ha}^{-1}$ rice straw compost (fresh weight) 
Table 8.3 A synthesis of straw management effects on rice yield in some studies in the Philippines and Vietnam

\begin{tabular}{|c|c|c|c|c|c|c|}
\hline Treatment & $\begin{array}{l}\text { Rate } \\
\mathrm{Kg} \\
\mathrm{ha}^{-1}\end{array}$ & $\begin{array}{l}\text { Location/ } \\
\text { country }\end{array}$ & Seasons ${ }^{\mathrm{a}}$ & $\begin{array}{l}\text { Soil } \\
\text { description }\end{array}$ & $\begin{array}{l}\text { Grain } \\
\text { yield }^{\text {b }} \\
\mathrm{Mg} \\
\text { ha }^{-1}\end{array}$ & Source \\
\hline No straw & & \multirow[t]{4}{*}{ Philippines } & & \multirow[t]{4}{*}{ Maahas clay } & $3.2 \mathrm{~b}$ & \multirow{4}{*}{$\begin{array}{l}\text { Banta and } \\
\text { Mendoza } \\
(1984)\end{array}$} \\
\hline Straw burned & & & & & $3.4 \mathrm{~b}$ & \\
\hline Straw incorporated & & & & & $4.1 \mathrm{a}$ & \\
\hline Straw composted & & & & & $4.2 \mathrm{a}$ & \\
\hline No straw & & \multirow[t]{2}{*}{ Philippines } & & & 77 & \multirow{2}{*}{$\begin{array}{l}\text { Banta and } \\
\text { Mendoza } \\
\text { (1984) }\end{array}$} \\
\hline Straw incorporated & 5000 & & & & 112 & \\
\hline No straw & & \multirow{2}{*}{$\begin{array}{l}\text { IRRI, } \\
\text { Philippines }\end{array}$} & \multirow[t]{2}{*}{$10 \mathrm{DS}$} & Silty clay & $3.79 \mathrm{e}$ & \multirow{6}{*}{$\begin{array}{l}\text { Cassman } \\
\text { et al. (1996) }\end{array}$} \\
\hline Straw incorporated & 116 & & & Silty clay & $4.70 \mathrm{~d}$ & \\
\hline No straw & & \multirow{2}{*}{$\begin{array}{l}\text { Victoria, } \\
\text { Philippines }\end{array}$} & \multirow[t]{2}{*}{$9 \mathrm{DS}$} & Clay & $3.83 \mathrm{~d}$ & \\
\hline Straw incorporated & 116 & & & Clay & $4.93 \mathrm{c}$ & \\
\hline No straw & & \multirow{2}{*}{$\begin{array}{l}\text { IRRI, } \\
\text { Philippines }\end{array}$} & \multirow[t]{2}{*}{$11 \mathrm{WS}$} & Silty clay & $3.39 \mathrm{~d}$ & \\
\hline Straw incorporated & 58 & & & Silty clay & $3.57 \mathrm{c}$ & \\
\hline No straw & & \multirow{2}{*}{$\begin{array}{l}\text { Victoria, } \\
\text { Philippines }\end{array}$} & \multirow[t]{2}{*}{$9 \mathrm{WS}$} & Clay & $3.22 \mathrm{~d}$ & \\
\hline Straw incorporated & 58 & & & Clay & $3.56 \mathrm{c}$ & \\
\hline No straw & & \multirow{3}{*}{$\begin{array}{l}\text { Can } \\
\text { Tho - } \\
\text { Vietnam }\end{array}$} & \multirow[t]{3}{*}{$3 \mathrm{DS}$} & \multirow{6}{*}{$\begin{array}{l}\text { Fluvaquentic } \\
\text { Humaquepts }\end{array}$} & 2.94 & \multirow{6}{*}{$\begin{array}{l}\text { Tuyen and } \\
\text { Tan (2001) }\end{array}$} \\
\hline Straw burned & & & & & 2.96 & \\
\hline Straw incorporated & & & & & 2.72 & \\
\hline No straw & & \multirow{3}{*}{$\begin{array}{l}\text { Can } \\
\text { Tho - } \\
\text { Vietnam }\end{array}$} & \multirow[t]{3}{*}{$3 \mathrm{DS}$} & & 5.70 & \\
\hline Straw burned & & & & & 5.50 & \\
\hline Straw incorporated & & & & & 5.59 & \\
\hline Raw rice straw & & \multirow{8}{*}{$\begin{array}{l}\text { An Giang } \\
\text { Province, } \\
\text { Vietnam }\end{array}$} & \multirow[t]{8}{*}{$1 \mathrm{DS}$} & & $2.83 \mathrm{c}$ & \multirow{8}{*}{$\begin{array}{l}\text { Son et al. } \\
(2013)\end{array}$} \\
\hline Composted rice straw & & & & & $2.95 \mathrm{c}$ & \\
\hline $\begin{array}{l}\text { Raw rice straw }+70 \% \\
\text { NPK }\end{array}$ & & & & & $4.71 \mathrm{~b}$ & \\
\hline $\begin{array}{l}\text { Composted rice straw } \\
+70 \% \text { NPK }\end{array}$ & & & & & $5.32 \mathrm{a}$ & \\
\hline $\begin{array}{l}\text { Burned rice straw } \\
+70 \% \mathrm{NPK}\end{array}$ & & & & & $4.77 \mathrm{~b}$ & \\
\hline $\begin{array}{l}\text { Burned rice straw } \\
+100 \% \text { NPK }\end{array}$ & & & & & $5.11 \mathrm{ab}$ & \\
\hline $\begin{array}{l}\text { Raw rice straw } \\
+100 \% \text { NPK }\end{array}$ & & & & & $5.30 \mathrm{a}$ & \\
\hline $\begin{array}{l}\text { Composted rice } \\
\text { straw }+100 \% \text { NPK }\end{array}$ & & & & & $5.33 \mathrm{a}$ & \\
\hline
\end{tabular}


Table 8.3 (continued)

\begin{tabular}{|c|c|c|c|c|c|c|}
\hline Treatment & $\begin{array}{l}\text { Rate } \\
\mathrm{Kg} \\
\mathrm{ha}^{-1}\end{array}$ & $\begin{array}{l}\text { Location/ } \\
\text { country }\end{array}$ & Seasons ${ }^{\mathrm{a}}$ & $\begin{array}{l}\text { Soil } \\
\text { description }\end{array}$ & $\begin{array}{l}\text { Grain } \\
\text { yield }^{\mathrm{b}} \\
\mathrm{Mg} \\
\mathrm{ha}^{-1}\end{array}$ & Source \\
\hline $\begin{array}{l}\text { No straw; no } \\
\text { additional NPK }\end{array}$ & & \multirow{3}{*}{$\begin{array}{l}\text { Can } \\
\text { Tho - } \\
\text { Vietnam }\end{array}$} & \multirow[t]{4}{*}{4} & \multirow[t]{4}{*}{$\begin{array}{l}\text { Typic } \\
\text { Humaquept }\end{array}$} & $3.79^{\mathrm{c}}$ & \multirow[t]{4}{*}{$\begin{array}{l}\text { Watanabe } \\
\text { et al. (2013) }\end{array}$} \\
\hline $\begin{array}{l}\text { Straw incorporated; } \\
\text { no additional NPK }\end{array}$ & 6000 & & & & $4.81^{\mathrm{c}}$ & \\
\hline $\begin{array}{l}\text { Straw incorporated + } \\
\text { NPK } \\
\left(40,12,12 \mathrm{~kg} \mathrm{ha}^{-1}\right)\end{array}$ & 6000 & & & & $6.06^{\mathrm{c}}$ & \\
\hline $\begin{array}{l}\text { Straw incorporated + } \\
\text { NPK } \\
\left(60,18,18 \mathrm{~kg} \mathrm{ha}^{-1}\right)\end{array}$ & 6000 & & & & $6.04^{c}$ & \\
\hline No straw; no NPK & & \multirow{7}{*}{$\begin{array}{l}\text { Can } \\
\text { Tho - } \\
\text { Vietnam }\end{array}$} & \multirow[t]{7}{*}{4} & & $4.19^{\mathrm{d}}$ & \multirow{7}{*}{$\begin{array}{l}\text { Watanabe } \\
\text { et al. (2017) }\end{array}$} \\
\hline $\begin{array}{l}\text { Straw incorporated; } \\
\text { no NPK }\end{array}$ & 6000 & & & & $4.91^{\mathrm{d}}$ & \\
\hline $\begin{array}{l}\text { No straw + inorganic } \\
40 \% \text { NPK }\end{array}$ & & & & & $5.33^{\mathrm{d}}$ & \\
\hline $\begin{array}{l}\text { Straw incorporated } \\
+40 \% \text { NPK }\end{array}$ & 6000 & & & & $5.95^{\mathrm{d}}$ & \\
\hline $\begin{array}{l}\text { No straw }+60 \% \\
\text { inorganic NPK }\end{array}$ & & & & & $5.48^{\mathrm{d}}$ & \\
\hline $\begin{array}{l}\text { Straw incorporated } \\
+60 \% \text { NPK }\end{array}$ & 6000 & & & & $5.90^{\mathrm{d}}$ & \\
\hline $\begin{array}{l}\text { No straw }+100 \% \\
\text { NPK }\end{array}$ & & & & & $4.94^{\mathrm{d}}$ & \\
\hline
\end{tabular}

a Seasons means number of seasons; $D S$ dry season; WS wet season; numbers without letters means the season type is not specified

${ }^{b}$ Treatment means followed by the same lowercase letter within the same study are not significantly different at $p<0.05$

${ }^{\mathrm{c}}$ Average grain yield over four seasons from 2011 to 2013

${ }^{\mathrm{d}}$ Average grain yield over four seasons from 2009 to 2011

increased rice yield where no mineral fertilizer was applied in the wet season (Table 8.3). In the same study, they also observed positive effects of rice straw compost on physical soil properties including a lower penetration resistance compared to where no compost was applied. In China, rice yield was greater with rice straw incorporation than removal under conventional tillage where no nitrogen fertilizer was added (Xu et al. 2010). A 3-year study conducted across three rice-growing sites in Asia showed little or no benefit of incorporated rice or wheat straw for the succeeding crop (Thuy et al. 2008). However, at a site in India the incorporation of rice straw 20 days before sowing wheat without $\mathrm{N}$ fertilization significantly decreased wheat yield but increased yield of rice that followed after wheat. In contrast, in East China incorporation of rice straw increased wheat yield by about 28\% compared to no straw control, but had no significant effects on rice yield (Zhang et al. 2015). 
A study conducted on a rice-wheat cropping system in India over 4 years showed greater yields of wheat where rice and wheat straw were incorporated compared to where it was removed or burned (Gupta et al. 2007). In contrast, straw management did not affect rice yields. A meta-analysis conducted in China showed that retention of rice straw increased rice yields by $5.2 \%$, but that the yield benefit increased with duration of straw incorporation, i.e., time after repeated application (Huang et al. 2013). In a study in India, wheat grain yield was $13 \%$ greater when rice straw was incorporated in the soil compared to when it was removed. A recent study in India showed that cereal yields, i.e., rice, wheat, and maize, are greater where straw is incorporated than where it is removed under a diversified cropping system and different combinations of tillage and crop establishment methods (Nandan et al. 2018). While the rice yield increased from $3.0 \%$ to $8.2 \%$, the yield benefits were greater for maize and wheat, likely due to a combination of moisture conservation under upland conditions and nutrient contribution from the incorporated straw.

\subsection{Paddy Soil Degradation Associated with Straw Removal}

While straw incorporation is labor-intensive and requires machinery for effective mixing with the soil, especially where rice yields are high, straw burning has negative impacts on soil fertility and soil organic C (Prasad et al. 1999; Surekha et al. 2003). The heat and duration of fire; soil moisture, both at the time of burning and during tillage; the time elapsed and climatic condition between burning and tillage; and the chemical, physical, and biological properties of the soil will all influence the change in soil properties resulting from burning rice straw. The impact of straw burning on soil fertility accumulates over time. Ponnamperuma (1984) highlighted the need to consider experimenting with duration when drawing conclusions about the sustainability of straw burning. However, research indicates that the advantages of burning are offset by the disadvantages, including nutrient loss, depletion of soil organic C, and reduction in the presence of beneficial soil biota (Mandal et al. 2004). Nonetheless, the ash from burning rice straw is rich in $\mathrm{K}$ and, thus, the practice of straw burning resulted in recycling of $\mathrm{K}$, but with a loss of $\mathrm{N}$ and $\mathrm{P}$.

Potassium recycling is influenced by straw management since more than $80 \%$ of the $\mathrm{K}$ taken up by rice is in straw (Dobermann and Fairhurst 2000). Consequently, $\mathrm{K}$ deficiencies are common in soils where rice straw is removed. In a study conducted under rainfed conditions in Thailand, Whitbread et al. (2003) calculated negative $\mathrm{K}$ and $\mathrm{S}$ balances when rice straw was removed. Similarly, straw management influences $\mathrm{Si}$, which has been shown to be beneficial in rice growth. Si dynamics in the soil is affected by straw management (Seyfferth et al. 2013; Wickramasinghe and Rowell 2006). For example, soil-available Si was low in Vietnam where crop residues are removed from the fields while in the Philippines there is high availabil- 
ity due to crop residue retention (Settele et al. 2018). Removal of rice straw from the field has been practiced widely in South Asia and has been associated with $\mathrm{K}$ and $\mathrm{Si}$ deficiencies influencing rice productivity (Wickramasinghe and Rowell 2006). Removal of rice straw from the field can cause numerous direct and indirect adverse impacts on the ecosystem including depletion of soil organic C. Important direct impacts of removal are low input of $\mathrm{C}$ biomass, reduction in nutrients/elemental cycling and decrease in food/energy source for soil biota along with the attendant decline in soil quality (Vijayaprabhaka et al. 2017).

\subsection{Constraints, Trends, and Recommendations}

Increasingly, rice straw is incorporated in fields where rice is grown. This is more so with the increasing use of combine harvesters that leave all the crop residues in the field compared to the traditional manual harvesting where only a portion of the straw was retained in the field. There are benefits associated with the incorporation of rice straw in the soil, including greater yields, nutrient cycling, soil organic matter build-up, and a general benefit on ecosystem services. However, there is a need to consider timing of application and water management to maximize the benefits of straw in the soil and reduce the negative effects such as production of GHG emissions or release of phenolic compounds that affect nutrient availability. This brings into question the practicality of straw incorporation on intensive systems, e.g., triple rice cropping where there is little time between crops to allow for aerobic decomposition. This suggests that solutions for straw management need to be tailored to suit farmer conditions. In situations where triple rice cropping is mechanized, there is a need to consider cost-effective alternatives to straw management with documentation of the experiences to enable extension workers to give informed recommendations to farmers.

In cases where combine harvesters are used, leaving large quantities of rice residue in the field, the practice of zero tillage with the use of seed drills is affected by residues clogging the machinery. Alternative equipment should be considered. There is also a need for studies to determine proportions of straw that can be left on the field with minimum effects on land preparation and establishment of the next crop. Options for collection of straw from the field, especially where combine harvesters are used, have been discussed elsewhere in this book, but decisions on whether to collect or leave straw in the field need to take into consideration the trade-offs of the different options. Nonetheless, there are benefits, in general, of returning rice straw to the field for sustainable cycling of nutrients and improving crop yields. 


\section{References}

Alberto MCR, Wassmann R, Gummert M, Buresh RJ, Quilty JR, Correa TQ Jr, Centeno CAR, Oca GM (2015) Straw incorporated after mechanized harvesting of irrigated rice affects net emissions of $\mathrm{CH}_{4}$ and $\mathrm{CO}_{2}$ based on eddy covariance measurements. Field Crop Res 184:162-175

Banta S, Mendoza CV (eds) (1984) Organic matter and rice. International Rice Research Institute http://books.irri.org/9711041049_content.pdf

Bi L, Zhang B, Liu G, Li Z, Liu Y, Ye C, Yu X, Lai T, Zhang J, Yin J (2009) Long-term effects of organic amendments on the rice yields for double rice cropping systems in subtropical China. Agric Ecosyst Environ 129:534-541

Bijay-Singh YS, Ladha JK, Khind CS, Khera TS, Bueno CS (2004) Effects of residue decomposition on productivity and soil fertility in rice-wheat rotation. Soil Sci Soc Am J 68:854-864

Bijay-Singh YS, Shan Y, Johnson-Beebout S, Yadvinder-Singh BR (2008) Crop residue management for lowland rice-based cropping systems in Asia. Adv Agron 98:117-199

Bird JA, Horwath WR, Eagle AJ, Van Kessel C (2001) Immobilization of fertilizer nitrogen in rice. Soil Sci Soc Am J 65:1143-1152

Cassman K, De Datta S, Amarante S, Liboon S, Samson M, Dizon M (1996) Long-term comparison of the agronomic efficiency and residual benefits of organic and inorganic nitrogen sources for tropical lowland rice. Exp Agric 32:427-444

Dobermann A, Fairhurst TH (2000) Rice: nutrient disorders and nutrient management. International Rice Research Institute http://books.irri.org/9810427425_content.pdf

Dobermann A, Fairhurst T (2002) Rice straw management. Better Crops Intl 16:7-11

Eagle AJ, Bird JA, Horwath WR, Linquis BA, Brouder SM, Hill JE, van Kessel C (2000) Rice yield and nitrogen utilization efficiency under alternative straw management practices. Agron J 92(6):1096-1103

Gangwar KS, Singh KK, Sharma SK, Tomar OK (2006) Alternative tillage and crop residue management in wheat after rice in sandy loam soils of Indo-Gangetic plains. Soil Tillage Res 88:242-252

Gupta R, Ladha J, Singh J, Singh G, Pathak H (2007) Yield and phosphorus transformations in a rice-wheat system with crop residue and phosphorus management. Soil Sci Soc Am J 71:1500-1507

Haefele S, Konboon Y, Wongboon W, Amarante S, Maarifat A, Pfeiffer E, Knoblauch C (2011) Effects and fate of biochar from rice residues in rice-based systems. Field Crop Res 121:430-440

Hoi NT, Ve NB, Tan PS, Giau TQ (2009) Effects of incorporated rice straw into the soil on rice growth and yield. Journal of Sciences. Can Tho University

Huang S, Zeng Y, Wu J, Shi Q, Pan X (2013) Effect of crop residue retention on rice yield in China: a meta-analysis. Field Crop Res 154:188-194

Majumder B, Mandal B, Bandyopadhyay P, Gangopadhyay A, Mani P, Kundu A, Mazumdar D (2008) Organic amendments influence soil organic carbon pools and rice-wheat productivity. Soil Sci Soc Am J 72:775-785

Mandal KG, Misra AK, Hati KM, Bandyopadhyay KK, Ghosh PK, Mohanty M (2004) Rice residue-management options and effects on soil properties and crop productivity. J Food Agric Environ 2:224-231

Naklang K, Whitbread A, Lefroy R, Blair G, Wonprasaid S, Konboon Y, Suriya-arunroj D (1999) The management of rice straw, fertilizers and leaf litters in rice cropping systems in Northeast Thailand. Plant Soil 209:2-128

Nandan R, Singh S, Kumar V, Singh V, Hazra K, Nath C, Malik R, Poonia S, Solanki CH (2018) Crop establishment with conservation tillage and crop residue retention in rice-based cropping systems of eastern India: yield advantage and economic benefit. Paddy Water Environ 16:477-492

Olk DC, Cassman KG, Schmidt-Rohr K, Anders MM, Mao JD, Deenik JL (2006) Chemical stabilization of soil organic nitrogen by phenolic lignin residues in anaerobic agroecosystems. Soil Biol Biochem 38:3303-3312 
Pampolino MF, Laureles EV, Gines HC, Buresh RJ (2008) Soil carbon and nitrogen changes in long-term continuous lowland rice cropping. Soil Sci Soc Am J 72:798-807

Ponnamperuma F (1984) Straw as a source of nutrients for wetland rice. Organic Matter Rice $117: 136$

Prasad R, Gangaiah B, Aipe K (1999) Effect of crop residue management in a rice-wheat cropping system on growth and yield of crops and on soil fertility. Exp Agric 35:427-435

Sander BO, Samson M, Buresh RJ (2014) Methane and nitrous oxide emissions from flooded rice fields as affected by water and straw management between rice crops. Geoderma 235:355-362

Schmidt A, Auge H, Brandl R, Heong KL, Hotes S, Settele J, Villareal S, Schädler M (2015) Small-scale variability in the contribution of invertebrates to litter decomposition in tropical rice fields. Basic Appl Ecol 16:674-680

Settele J, Heong KL, Kühn I, Klotz S, Spangenberg JH, Arida G, Beaurepaire A, Beck S, Bergmeier E, Burkhard B (2018) Rice ecosystem services in Southeast Asia. Springer

Seyfferth AL, Kocar BD, Lee JA, Fendorf S (2013) Seasonal dynamics of dissolved silicon in a rice cropping system after straw incorporation. Geochim Cosmochim Acta 123:120-133

Sidhu H, Humphreys E, Dhillon S, Blackwell J, Bector V (2007) The Happy Seeder enables direct drilling of wheat into rice stubble. Aust J Exp Agric 47:844-854

Son TTN, Thu TTA, Nam NN, Man LH (2013) Influence of rice straw treated by indigenous Trichoderma spp. on soil fertility, rice grain yield, and economic efficiency in the Mekong Delta. Methods 60:145-152

Surekha K, Kumari AP, Reddy MN, Satyanarayana K, Cruz PS (2003) Crop residue management to sustain soil fertility and irrigated rice yields. Nutr Cycl Agroecosyst 67:145-154

Thanh ND, Hoa HTT, Hung HC, Nhi PTP, Thuc DD (2016) Effect of fertilizer on rice yield improvement in coastal sandy soil of Thua Thien Hue province. Hue Univ J Sci Agric Rural Dev 119

Thuan HN, Long DT (2010) Use rice straw from previous season for the following season on degraded soil, Bac Giang province, Vietnam. J Sci Dev, Hanoi Agric University 8:843-849

Thuy NH, Shan Y, Bijay-Singh WK, Cai Z, Yadvinder-Singh BRJ (2008) Nitrogen supply in ricebased cropping systems as affected by crop residue management. Soil Sci Soc Am J 72:514-523

Trinh MV, Cuong V, Quynh VD, Thu NTH (2011) Study to produce biochar from rice straw and rice husk to enhance soil fertility, crop yield, and mitigate GHG emission. J Vietnam Agric Sci Technol 3

Trinh MV, Loan BTP, Van The T (2014) Developing crop residue collection, treatment of crop residue to reduce green house gas emission in rural area in Red River Delta, Report results of project from Ministry of Agriculture and Rural Development period 2011-2014

Tuyen TQ, Tan PS (2001) Effects of straw management and tillage practices on soil fertility and grain yield of rice. Omonrice 9:74-78

Vijayaprabhaka A, Nalliah Durairaj S, Vinoth Raj J (2017) Effect of rice straw management options on soil available macro and micro nutrients in succeeding rice field. Intl J Chem Stud 5:410-413

Watanabe T, Man LH, Vien DM, Khang VT, Ha NN, LinhTB IO (2009) Effects of continuous rice straw compost application on rice yield and soil properties in the Mekong Delta. Soil Sci Plant Nutr 55:754-763

Watanabe T, Luu HM, Nguyen NH, Ito O, Inubushi K (2013) Combined effects of the continual application of composted rice straw and chemical fertilizer on rice yield under a double rice cropping system in the Mekong Delta, Vietnam. Japan Agric Res Quart JARQ 47:397-404

Watanabe T, Luu HM, Inubushi K (2017) Effects of the continuous application of rice straw compost and chemical fertilizer on soil carbon and available silicon under a double rice cropping system in the Mekong Delta, Vietnam. Japan Agric Res Quart JARQ 51:233-239

Whitbread A, Blair G, Konboon Y, Lefroy R, Naklang K (2003) Managing crop residues, fertilizers and leaf litters to improve soil C, nutrient balances, and the grain yield of rice and wheat cropping systems in Thailand and Australia. Agric Ecosyst Environ 100:251-263 
Wickramasinghe DB, Rowell DL (2006) The release of silicon from amorphous silica and rice straw in Sri Lankan soils. Biol Fertil Soils 42:231-240

Witt C, Cassman K, Olk D, Biker U, Liboon S, Samson M, Ottow J (2000) Crop rotation and residue management effects on carbon sequestration, nitrogen cycling, and productivity of irrigated rice systems. Plant Soil 225:263-278

Xu Y, Nie L, Buresh RJ, Huang J, Cui K, Xu B, Gong W, Peng S (2010) Agronomic performance of late-season rice under different tillage, straw, and nitrogen management. Field Crop Res 115:79-84

Yadvinder-Singh, Bijay-Singh, Timsina J (2005) Crop residue management for nutrient cycling and improving soil productivity in rice-based cropping systems in the tropics. Adv Agron 85:269-407

Yadvinder-Singh B-S, Ladha J, Khind C, Khera T, Bueno C (2004) Effects of residue decomposition on productivity and soil fertility in rice-wheat rotation. Soil Sci Soc Am J 68:854-864

Zhang L, Zheng J, Chen L, Shen M, Zhang X, Zhang M, Bian X, Zhang J, Zhang W (2015) Integrative effects of soil tillage and straw management on crop yields and greenhouse gas emissions in a rice-wheat cropping system. Eur J Agron 63:47-54

Open Access This chapter is licensed under the terms of the Creative Commons Attribution 4.0 International License (http://creativecommons.org/licenses/by/4.0/), which permits use, sharing, adaptation, distribution and reproduction in any medium or format, as long as you give appropriate credit to the original author(s) and the source, provide a link to the Creative Commons licence and indicate if changes were made.

The images or other third party material in this chapter are included in the chapter's Creative Commons licence, unless indicated otherwise in a credit line to the material. If material is not included in the chapter's Creative Commons licence and your intended use is not permitted by statutory regulation or exceeds the permitted use, you will need to obtain permission directly from the copyright holder.

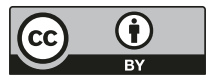

